\title{
Studying of Elastoplastic Properties of Coal Specimens Using Indentation Technique
}

\author{
A. O. Vatulyan, A. A. Lyapin, E. L. Kossovich
}

Alexander O. Vatulyan, https://orcid.org/0000-0003-0444-4496, Institute of Mathematics, Mechanics, and Computer Science named after of I. I. Vorovich, Southern Federal University, 105/42 Bolshaya Sadovaya St., Rostov on Don 344006, Russia, vatulyan@math.rsu.ru

Alexander A. Lyapin, http://orcid.org/0000-0001-8573-721X, Institute of Mathematics, Mechanics, and Computer Science named after of I. I. Vorovich, Southern Federal University, 105/42 Bolshaya Sadovaya St., Rostov on Don 344006, Russia, lyapin@sfedu.ru

Elena L. Kossovich, http://orcid.org/0000-0002-3358-6533, National University of Science and Technology „MISiS“, 4 Leninskii Ave., Moscow 119991, Russia, e.kossovich@misis.ru

A numerical study on elsatoplastic properties in problem of coals specimen nanoindentation by Berkovich pyramid is presented. The stress-strain state of specimen during indentation is calculated using finite element method including complex elastoplastic behaviour on the basis of Drucker-Prager model. The effective axisymmetrical indenter of cone shape is introduced and used for the simulation. The influence of basic geometrical and material parameters of the solid model on the indentation curve is studied. In addition, some new form of indentation curve approximation is proposed. For all the results calculated, the sets of approximation parameters are given. Using modern nanoindentation equipment the number of real experiments were performed and comparison with the mathematical model is presented.

Key words: coal, nanoindentation, material characterization, finite element method, elastoplastic.

DOI: https://doi.org/10.18500/1816-9791-2018-18-4-412-420

\section{INTRODUCTION}

The indentation technique for elastic bodies has been used for more than a hundred years and is an effective tool for measuring the various material properties of solids of different nature. Currently, a large number of industrial companies have been using this method in production and expertise, developing and manufacturing of more and more modern indentation equipment that allows controlling a number of experiment parameters: temperature, humidity, and surface quality of the test sample. The method is based on simultaneous measurement of the indentation force and the displacement of the indenter to construct a „P- $h$ “ (loading-unloading) curve - the basic information for further studying of the material parameters. The determination of the material contact hardness was initially introduced in [1], as the value proportional to the ratio of pressing force and the square of the indentation zone radius. To date, various forms of an indenter are used [2], including irregular forms, such as pyramids of various shapes, cones, and indenters with a smooth surface, such as sphere, cylinder [3]. Following the definition of the contact hardness, for the indifference of the experiment to the shape of indenter, the corresponding parameters must satisfy the requirement of equality of the footprint area under a similar load.

In 1992, the technique was published [4] to measure the hardness of a material on the basis of an indentation experiment, which was subsequently tested and implemented by a multitude of scientists in their studies on the mechanical properties at nano- or microlevels. The main result is the demonstration of a fact that the unloading curve is not linear even at the initial stages, and the proposed technique, taking into account the curvature of the unloading path, allows to determine the material parameters with an accuracy of 5 percent. 
It is necessary to distinguish materials investigated by the method of indentation within according to their nature. The matter is that materials of the coal or rocks types are largely different in their mechanical properties in comparison, for example, with metals. This difference lies in the various properties of the material behaviour under hydrostatic pressure. In particular, metals do not reach the zone of plasticity in the space of principal stresses under hydrostatic loading, in contrast to rock-like structures, including coals. This difference can be described by various forms of the yield surface: for such materials like metals, the surface is presented by a cylinder for the Mises model, while for the soil and rock materials it is presented by a cone, and the mechanical properties of such materials could be described by the Mohr-Coulomb model. During Berkovich pyramid indentation in the area of a tip the hydrostatic pressure is formed. Thus, for the correct description of the deformation process of rocks and coals in particular, it is necessary to use the Mohr-Coulomb model.

Significant number of works have been devoted to the identification of mechanical properties for coal rocks [5-8]. By its nature and process of formation, coal is an extremely complex material that has many peculiarities such as anisotropy, rheology, the presence of internal stresses, inhomogeneous properties, fracturing and many others. These significantly complicate the measurement of mechanical properties, because appropriate techniques for conducting the experiment, processing the obtained data, and mathematical models should consider the entire set of factors. Thus, the study of mechanical properties of coal rocks is an extremely unordinary and promising task.

The finite element method allows taking into account the complex geometry of the problem and simultaneously describes realistic physical and mechanical properties of the material in the time of stress-strain state calculation. In the article, the physical model of the sample and the indentation process are realized using ANSYS package. The model geometry describes $1 / 6$ of the Berkovich pyramid, taking into account the planes of symmetry, and the body of the test sample in the form of a prism, with a volume sufficient to disregard the influence of the sample boundaries. In the indentation zone, the mesh size is significantly reduced to achieve sufficient accuracy of the results.

To simulate both bodies, the finite element of SOLID186 type with a 20-node structure is used, which describes changes in the displacement fields, taking into account quadratic behaviour. Each node has three degrees of freedom: displacements along $\mathrm{x}, \mathrm{y}$, and $z$, respectively. The element supports various physical properties of the material, including plasticity and viscoelasticity.

The material properties of the test sample are described by the classical Drucker Prager model [9], which is applicable to granular materials such as soil, stone, concrete and other materials whose elastoplastic properties depend on hydrostatic pressure. The model uses the approximation of the yield surface in the form of a cone according to the Drucker - Prager law:

$$
f\left(I_{1}, J_{2}\right)=a I_{1}+\sqrt{J_{2}}-b
$$

where: $I_{1}$ is hydrostatic-dependent first principal invariants of stress, a characterizes the dependence on hydrostatic pressure, $J_{2}$ is the non-zero principal invariant of the deviatoric stress, $b$ is critical stress value.

Deformation of the indenter is described in terms of the linear elastic model with Young's modulus parameter of $865 \mathrm{GPa}$, Poisson's ratio of 0.17 . 


\section{APPROXIMATION OF CURVES AND EFFECT OF MODEL PARAMETERS}

The 3D model for studying the indentation process, even with symmetry taken into account, requires a significant time for calculation. In this case, one can use the simplification of the pyramidal indenter with a similar cone-like, which satisfies the requirement of the equal area of the tip print [10]. For the conical form of the indenter, an axisymmetric model can be constructed that will significantly reduce the calculation time [11]. The results of simulation for the three-dimensional model of the Berkovich pyramid and the axisymmetric model of a conical indenter with the tip angle of 71.8 degrees demonstrated very close values. Thus, the geometry of an effective indenter is chosen and subsequent investigations of the problem will be carried out based on an axisymmetric model.

According to [12], the unloading curves can be approximated by a power-law dependence of the pressing force on the depth, and for various materials the parameters of such power-law approximations are found and published.

In the process of coals testing by the nanoindentation method with the Berkovich pyramid, anomalous cases were observed, when the unloading curve passed above the loading one (see Fig. 1). The fact that work performed while unloading is greater

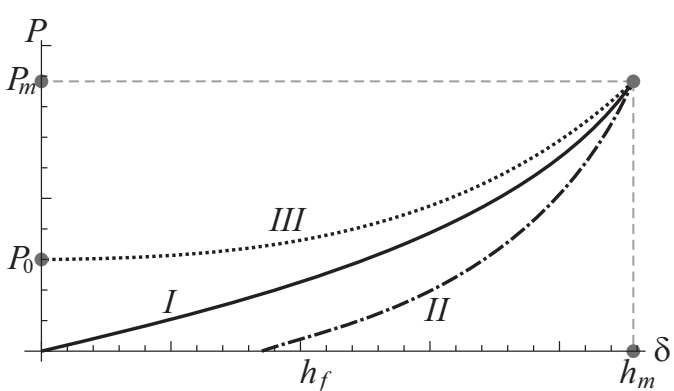

Fig. 1. Structure of the indentation diagram, curve $I$ - loading, curve $I I$ - unloading, curve $I I I$ - abnormal unloading that while loading part could be explained by some layer delamination due to a local buckling process in the near-surface zone at low loads [13].

In addition, the loading curve also contains sufficient information and can be the subject of research. Thus, we introduce several approximations for the loading, unloading and „anomalous“ unloading curves.

Let us bear in mind that the curves at maximum indentation force $P=P_{m}$ give the depth of indentation $h_{m}$. Taking this into account, one can reduce the number

of unknown parameters from 4 to 2 , since $P_{m}$ and $h_{m}$ parameters, generally speaking, are known from the experiment. Thus, the approximation functions of the loading and unloading curves can be represented in the form:

$$
\begin{gathered}
P_{I}(h)=P_{m}\left(\frac{h}{h_{m}}\right)^{n}, \quad P_{I I}(h)=P_{m}\left(\frac{h-h_{f}}{h_{m}-h_{f}}\right)^{m}, \\
P_{I I I}(h)=\left(P_{m}-P_{0}\right)\left(\frac{h}{h_{m}}\right)^{l}+P_{0} .
\end{gathered}
$$

Note that the unknown parameters $(n, m, l)$ of such an approximation are dimensionless, which is physically correct.

Let us now analyse the influence of mechanical and geometric parameters on the results of indentation. As a test sample, we will use the characteristics of fused silica, which is the most commonly used in identification experiments and has known stable characteristics [14].

We give further data on the effect of the Young's modulus parameter on the indentation curve. For the initial values of the problem parameters, we take the following: $E_{0}=73 \mathrm{GPa}, \nu_{0}=0.17, R_{0}=20 \mathrm{~nm}, a_{0}=0.821, b_{0}=4 \mathrm{GPa}$. 
Fig. 2 shows various indentation curves for several values of Young's modulus, all other parameters of the problem are fixed.

It can be seen, that the influence affects both the loading curve and the unloading part, with the changes starting from the very beginning of the loading process. Along the unloading part, the tangent line coefficient changes from the beginning. Such coefficient is an important parameter used in processing the re-

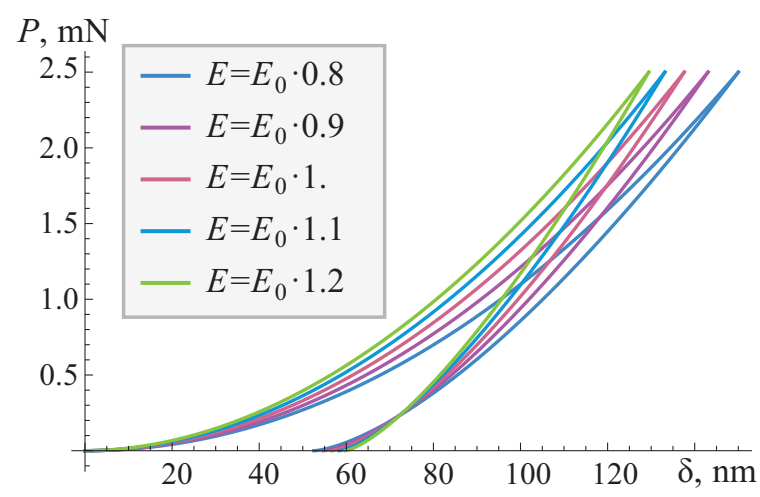

Fig. 2. Influence of Young's modulus on the indentation curve

sults of indentation. We also note that the unloading curves intersect at one point, which can also be the subject of a separate analysis.

The corresponding parameters of the approximation functions are given in the Table 1 .

Table 1

Approximation parameters of the indentation curves for different

values of the Young's modulus

\begin{tabular}{|c|c|c|c|c|c|}
\hline$E(\mathrm{GPa})$ & $n$ & $m$ & $h_{m}(\mathrm{~nm})$ & $P_{m}(\mathrm{mN})$ & $h_{f}(\mathrm{~nm})$ \\
\hline 58.4 & 1.99 & 1.43 & 151.13 & 2.5 & 54.55 \\
65.7 & 1.99 & 1.41 & 143.9 & 2.5 & 56.51 \\
73 & 2.013 & 1.41 & 137.54 & 2.5 & 57.685 \\
80.3 & 2.016 & 1.39 & 132.42 & 2.5 & 58.78 \\
87.6 & 2.01 & 1.38 & 128.2 & 2.5 & 59.82 \\
\hline
\end{tabular}

Poisson's ratio is the characteristic of the test sample, which must be known in advance before performing the indentation experiment. Fig. 3 shows the results of numerical simulation for various values of the Poisson's ratio. It can be seen, that the parameter of the tangent line to the initial unloading section is practically not affected by the Poisson's ratio the unloading curves are displaced in parallel to each other. At the same time, loading parts differ from each other and can serve as information for determining the value of this parameter.

The corresponding parameters of the approximation functions are given in the Table 2.

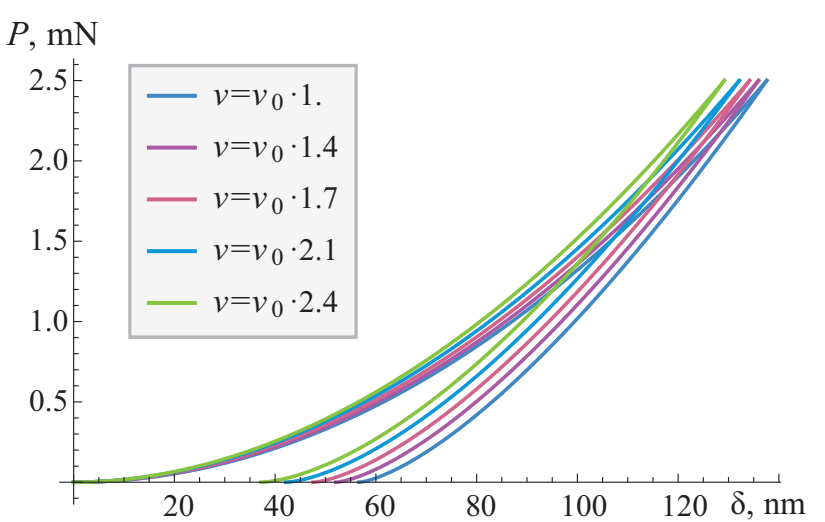

Fig. 3. Influence of Poisson's ratio on the indentation curve

Note that after a large number of identification experiments, the indenter tip wears out, which leads to the formation of a rounding in the vicinity of the vertex. Fig. 4 shows the influence of the radius of indenter tip on the loading curves. The effect manifests itself both in the loading and unloading parts. 
Table 2

Approximation parameters of the indentation curves for different values of the Poisson's ratio

\begin{tabular}{|c|c|c|c|c|c|}
\hline$\nu$ & $n$ & $m$ & $h_{m}(\mathrm{~nm})$ & $P_{m}(\mathrm{mN})$ & $h_{f}(\mathrm{~nm})$ \\
\hline 0.17 & 2.014 & 1.41 & 137.54 & 2.5 & 57.68 \\
0.23 & 2.014 & 1.44 & 135.6 & 2.5 & 53.19 \\
0.29 & 2.01 & 1.48 & 133.47 & 2.5 & 48.61 \\
0.35 & 1.99 & 1.51 & 131.13 & 2.5 & 44.31 \\
0.41 & 1.98 & 1.55 & 128.53 & 2.5 & 40.01 \\
\hline
\end{tabular}

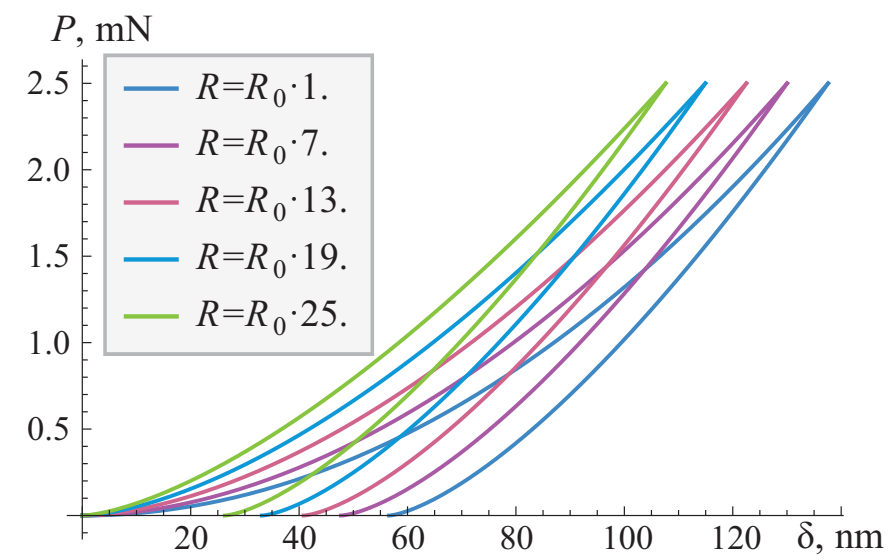

Fig. 4. Influence of the indenter tip radius on the indentation curve

The corresponding parameters of the approximation functions are given in the Table 3 .

Table 3

Approximation parameters of the indentation curves for different values of the indenter tip radius

\begin{tabular}{|c|c|c|c|c|c|}
\hline$R(\mathrm{~nm})$ & $n$ & $m$ & $h_{m}(\mathrm{~nm})$ & $P_{m}(\mathrm{mN})$ & $h_{f}(\mathrm{~nm})$ \\
\hline 20 & 2.01 & 1.40 & 137.54 & 2.5 & 57.68 \\
140 & 1.86 & 1.41 & 130.06 & 2.5 & 50.20 \\
260 & 1.72 & 1.41 & 122.58 & 2.5 & 42.40 \\
380 & 1.60 & 1.43 & 115.21 & 2.5 & 34.34 \\
500 & 1.51 & 1.44 & 107.8 & 2.5 & 26.88 \\
\hline
\end{tabular}

The parameters of the plastic model also have a significant effect on the shape of the indentation curve (Fig. 5). At the initial section of the curve, the effect is insufficient (plastic deformations have not yet spread from the vertex of the indenter), with increasing indentation the difference rises, the unloading curves differ in lesser manner and mainly differ only in the value of the residual deformation, depending on the specific parameter, but the tangential coefficients at the beginning of the unloading segments differ slightly.

The corresponding parameters of the approximation functions for the plasticity parameters $a$ and $b$ are given in the Table 4 and Table 5 . 

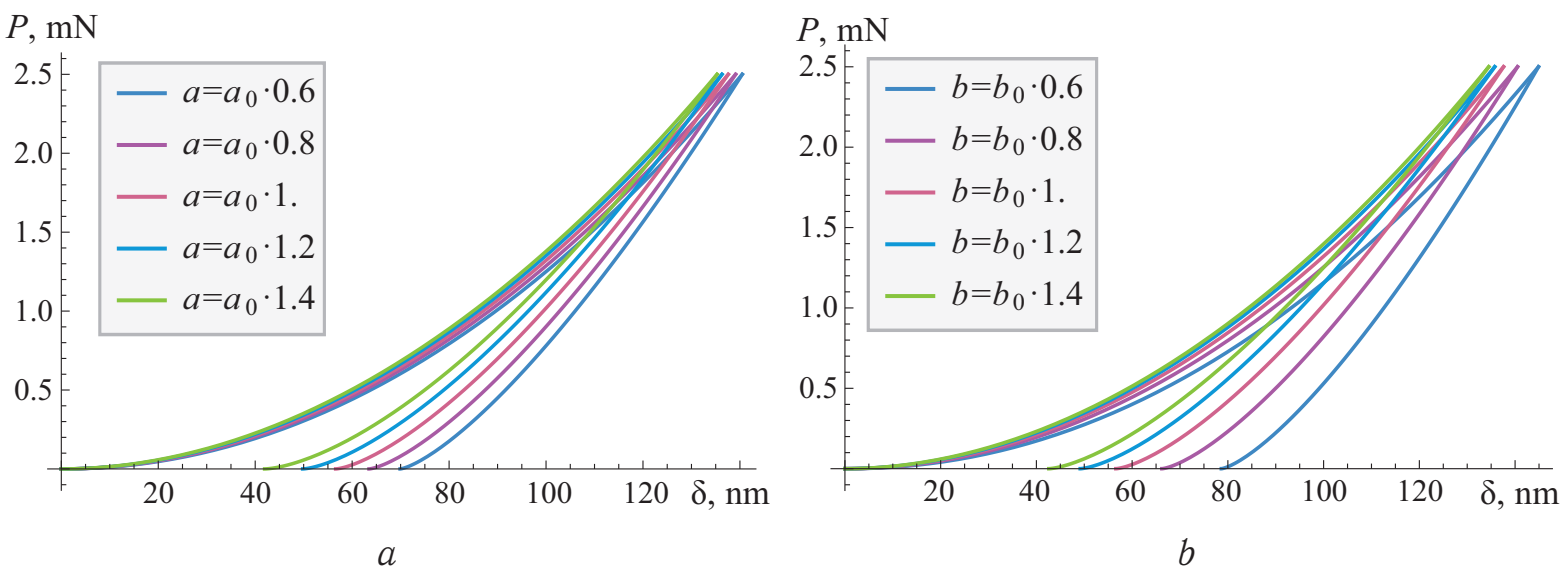

Fig. 5. Influence of the plasticity parameter $a$ and $b$ on the indentation curve

Table 4

Approximation parameters of the indentation curves

for different values of the plasticity parameter $a$

\begin{tabular}{|c|c|c|c|c|c|}
\hline$a$ & $n$ & $m$ & $h_{m}(\mathrm{~nm})$ & $P_{m}(\mathrm{mN})$ & $h_{f}(\mathrm{~nm})$ \\
\hline 0.4926 & 1.97 & 1.32 & 142.4 & 2.5 & 72.08 \\
0.6568 & 1.99 & 1.36 & 139.7 & 2.5 & 64.82 \\
0.821 & 2.013 & 1.41 & 137.54 & 2.5 & 57.68 \\
0.9852 & 2.015 & 1.45 & 135.89 & 2.5 & 50.89 \\
1.1494 & 2.011 & 1.52 & 134.59 & 2.5 & 43.53 \\
\hline
\end{tabular}

Table 5

Approximation parameters of the indentation curves

for different values of the plasticity parameter $b$

\begin{tabular}{|c|c|c|c|c|c|}
\hline$b(\mathrm{GPa})$ & $n$ & $m$ & $h_{m}(\mathrm{~nm})$ & $P_{m}(\mathrm{mN})$ & $h_{f}(\mathrm{~nm})$ \\
\hline 0.49 & 2.08 & 1.37 & 146.69 & 2.5 & 80.92 \\
0.66 & 2.03 & 1.41 & 142.11 & 2.5 & 68.52 \\
0.82 & 1.99 & 1.44 & 137.54 & 2.5 & 57.68 \\
0.99 & 1.97 & 1.45 & 135.18 & 2.5 & 49.99 \\
1.1 & 1.96 & 1.47 & 133.7 & 2.5 & 43.54 \\
\hline
\end{tabular}

Thus, the influence analysis for various elasto-plastic parameters on indentation curves is carried out, approximations of various types of loading and unloading curves are presented.

\section{COMPARISON OF RESULTS FOR NUMERICAL SIMULATION WITH EXPERIMENTAL DATA ON NANOINDENTATION OF COAL SPECIMENS}

A group of experiments was conducted on indentation of coal samples of various types. The specimens are thin sections of brown and hard coal and one, which includes both vitrinite and a large number of liptinite inclusions. The measurements were carried out using Hysitron Tribo Indentor TI 700 UBI instrument. The surface of the samples, prepared for indentation, was oriented perpendicularly to the bedding.

The micro-components identification was carried out with the preliminary use of microscopy in transmitted light, as well as microscopy in reflected light. The indentation 
areas on the instrument were determined by comparing the areas (micro-components) selected on microscopes with the image obtained with the built-in scanning probe microscope.

The maximal load during the measurements was selected in such a way so to achieve statistically reliable results (elastic moduli) on the vitrinite micro-components. The selection process consisted in selecting an optically homogeneous region and applying the grid with a 10- $\mu \mathrm{m}$ pitch, different forces were set in each of the grid nodes, varying within certain limits $(500-5000 \mu N$ or $5000-12000 \mu N)$.

The finite element model contains a number of parameters that must be selected to ensure the similarity of the theoretical indentation curve and experimental one. Fig. 6 shows the results of comparing the model and real data. A good coincidence of the results at the loading part was achieved, while the model and experiment unloading parts are slightly different. Such a difference can be related to the more complex physical and mechanical properties of coal rocks than those represented by a given mathematical model.

The experimental data correspond to thin vitrinite cross-section, the direction of the section is perpendicular to the bedding, the maximum load is $2.5 \mathrm{mN}$. By the least squares method the approximation parameters of the indentation curve for the coal sample $n=1.72, m=2.43$ were determined.

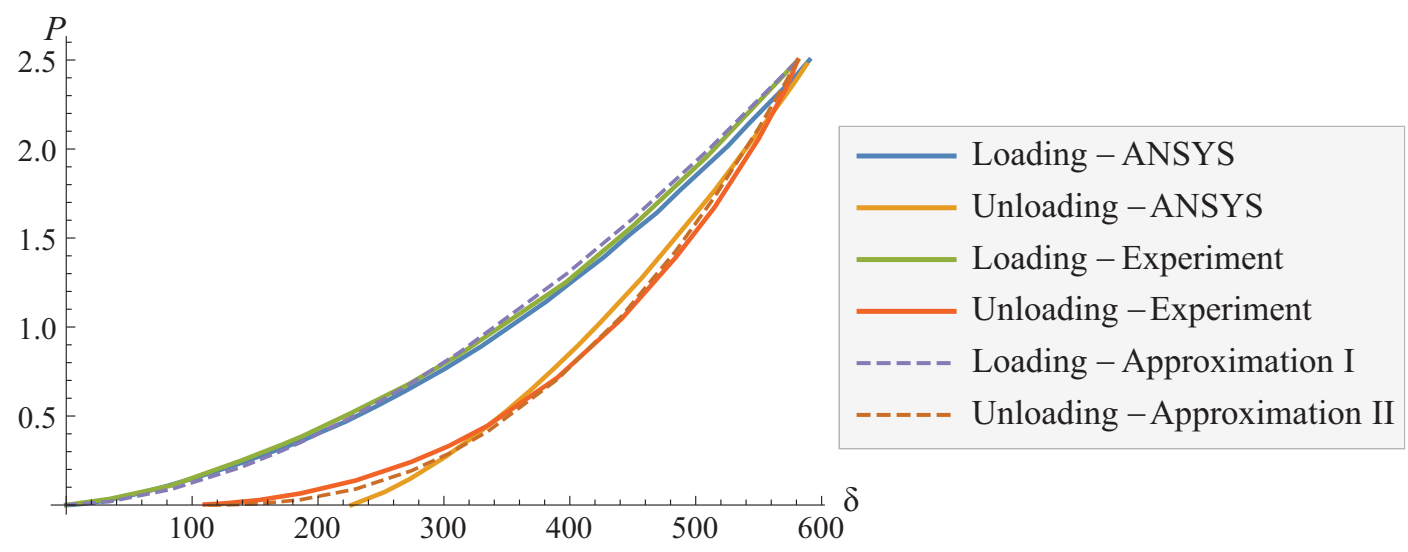

Fig. 6. Camparison of simulation results with experimental data and approximation functions given by (2)

Parameters of the mathematical model: radius of the indenter tip $R=1200 \mathrm{~nm}$, Young's modulus of the sample $E=2.7 \mathrm{GPa}$, Poisson's ratio $\nu=0.37$, parameters of the Drucker - Prager elastoplastic model $a=0.721, b=0.14 \mathrm{GPa}$.

\section{CONCLUSION}

Thus, the finite element model of the nanoindentation process for a coal sample is constructed taking into account the material elastoplastic properties described by the Drucker-Prager model; a number of numerical experiments were carried out; the influence of the elastoplastic and geometric parameters of the model on the loading curve of the sample is studied. With the use of modern experimental equipment, a number of full-scale experiments on the indentation of coal sections was carried out, the curves obtained are approximated by the model curves for determining the parameters of the computational model. The results demonstrated adequate convergence of the model and experiment, but also require the introduction of additional physical properties into the 
model for a more detailed description of all the phenomena during the process of coal specimens indentation.

Acknowledgements: This work was supported by the Russian Science Foundation (project no. 16-17-10217).

\section{References}

1. Meyer E. Untersuchen über Härteprüfung und Härte. Zeitschrift des Vereins deutschen Ingenieure, 1908, vol. 52, pp. 645-654.

2. Chang A. C., Liu B. H. Modified flat-punch model for hyperelastic polymeric and biological materials in nanoindentation. Mechanics of Materials, 2018, vol. 118, pp. 17-21. DOI: https://doi.org/10.1016/j.mechmat.2017.12.010

3. Zhankun Sun, Fuguo Li, Jun Cao, Xinkai Ma, Jinghui Li. Study on concavity-convexity transition of loading curve for spherical indentation. Mechanics of Materials, 2017, vol. 114, pp. 107-118. DOI: https://doi.org/10.1016/j.mechmat.2017.07.006

4. Oliver W. C., Pharr G. M. An improved technique for determining hardness and elastic modulus using load and displacement sensing indentation experiments. J. Mater. Res., 1992, vol. 7, iss. 6, pp. 1564-1583. DOI: https://doi.org/10.1557/JMR.1992.1564

5. Das B. The effect of load on Vicker's indentation hardness of coal. International Journal of Rock Mechanics and Mining. Sciences \& Geomechanics Abstracts, 1972, vol. 9, iss. 6, pp. 783-788. DOI: https://doi.org/10.1016/0148-9062(72)90036-8

6. Kossovich E., Epshtein S., Dobryakova N., Minin M., Gavrilova D. Mechanical properties of thin films of coals by nanoindentation. In: Karev V., Klimov D., Pokazeev K. (eds.) PMMEEP 2017: Physical and Mathematical Modeling of Earth and Environment Processes. Springer Geology. Springer, Cham, 2018, pp. 45-50. DOI: https://doi.org/10.1007/978-3319-77788-7_6

7. Kossovich E. L., Epshtein S. A., Shkuratnik V. L., Minin M. G. Perspectives and problems of modern depth-sensing indentation techniques application for diagnostics of coals mechanical properties. Gornyi Zhurnal, 2017, no. 12, pp. 25-30 (in Russian). DOI: https://doi.org/10.17580/gzh.2017.12.05

8. Kossovich E., Dobryakova N., Epshtein S., Belov D. Mechanical properties of coal microcomponents under continuous indentation. Journal of Mining Science, 2016, vol. 52, iss. 5, pp. 906-912. DOI: https://doi.org/10.1134/S1062739116041382

9. Drucker D. C., Prager W. Soil mechanics and plastic analysis or limit design. Quarterly of Applied Mathematics, 1952, vol. 10, no. 2, pp. 157-165.

10. Hernot X., Bartier O., Mauvoisin G., Collin J.-M. A universal formulation for indentation whatever the indenter geometry. Mechanics of Materials, 2015, vol. 81, pp. 101-109. DOI: https://doi.org/10.1016/j.mechmat.2014.11.006

11. Shim S., Oliver W., Pharr G. A critical examination of the berkovich vs. conical indentation based on 3d finite element calculation. MRS Proceedings, 2004, vol. 841, R9.5. DOI: https://doi.org/10.1557/PROC-841-R9.5

12. Oliver W. C., Pharr G. M. Measurement of hardness and elastic modulus by instrumented indentation: Advances in understanding and refinements to methodology. J. Mater. Res. 2004, vol. 19, iss. 1, pp. 3-20. DOI: https://doi.org/10.1557/jmr.2004.19.1.3

13. Vatul'yan A. O., Kossovich E. L., Plotnikov D. K. Some specific characteristics of indentation of cracked layered structures. Mechanics of Solids, 2017, vol. 52, iss. 4, pp. 429-434. DOI: https://doi.org/10.3103/S0025654417040094

14. Gadelrab K. R., Bonilla F. A., Chiesa M. Densification modeling of fused silica under nanoindentation. Journal of Non-Crystalline Solids, 2012, vol. 358, iss. 2, pp. 392-398. DOI: https://doi.org/10.1016/j.jnoncrysol.2011.10.011 


\title{
Cite this article as:
}

Vatulyan A. O., Lyapin A. A., Kossovich E. L. Studying of Elastoplastic Properties of Coal Specimens Using Indentation Technique. Izv. Saratov Univ. (N. S.), Ser. Math. Mech. Inform., 2018, vol. 18, iss. 4, pp. 412-420. DOI: https://doi.org/10.18500/1816-9791-2018-18-4-412-420

УДК 539.37

\section{ИССЛЕДОВАНИЕ УПРУГОПЛАСТИЧЕСКИХ СВОЙСТВ УГОЛЬНЫХ ПОРОД НА ОСНОВЕ МЕТОДА ИНДЕНТИРОВАНИЯ}

\begin{abstract}
А. О. Ватульян, А. А. Ляпин, Е. Л. Коссович
Ватульян Александр Ованесович, доктор фризико-математических наук, заведующий кафредрой теории упругости, Институт математики, механики и компьютерных наук имени И. И. Воровича, Южный фредеральный университет, Россия, 344006, Ростов-на-Дону, Б. Садовая, 105/42, vatulyan @ math.rsu.ru Ляпин Александр Александрович, кандидат фризико-математических наук, старший научный сотрудник, Институт математики, механики и компьютерных наук имени И. И. Воровича, Южный фредеральный университет, Россия, 344006, Ростов-на-Дону, Б. Садовая, 105/42, lyapin@sfedu.ru

Коссович Елена Леонидовна, кандидат сризико-математических наук, старший научный сотрудник, НУИЛ «Физико-химии углей» НИТУ «МИСиС», Россия, 119991, Москва, Ленинский просп., 4, e.kossovich@misis.ru

Проведено исследование упругопластических свойств образца на основе метода наноиндентирования пирамидой Берковича. Напряженно-десрормированное состояние образца в процессе индетирования определено на основе метода конечного элемента с учетом упругопластического поведения материала, описываемого моделью Друкера - Прагера. Введена эфрфрективная фрорма индентора в виде конуса, раствор которого был определен из анализа трехмерной и осесимметричной задач. Изучено влияние основных геометрических и материальных параметров упругой модели на фрорму кривой нагружения. Предложены законы аппроксимации кривых индентирования, параметры которых определены и представлены для всех вычислительных экспериментов. С применением современного экспериментального оборудования проведены эксперименты по индентированию реальных образцов угля, проведено сравнение с вычислительной моделью.
\end{abstract}

Ключевые слова: уголь, наноиндентирование, определение свойств материала, метод конечного элемента, упругопластичность.

Благодарности. Работа выполнена при финансовой поддержке Российского научного фонда (проект № 16-17-10217).

\section{Образец для цитирования:}

Vatulyan A. O., Lyapin A. A., Kossovich E. L. Studying of Elastoplastic Properties of Coal Specimens Using Indentation Technique [Ватульян А. О., Ляпин А. А., Коссович Е. Л. Исследование упругопластических свойств угольных пород на основе метода индентирования] // Изв. Сарат. ун-та. Нов. сер. Сер. Математика. Механика. Информатика. 2018. Т. 18, вып. 4. C. 412-420. DOI: https://doi.org/10.18500/1816-9791-2018-18-4-412-420 